\title{
GELENEKSEL YAPILARDA YAŞLI VE ENGELLİ ERIŞILEBIILIRLIGGIININ İRDELENMESİ: MALATYA-BALABAN GELENEKSEL EVLERİ ÖRNEĞİ
}

Nihal Arda AKYILDIZ

Tuba Nur OLĞUN²

$\ddot{O} z$

İnsan için yapılan her tasarımda; bireyin yaşam kalitesi, sağlık, güvenlik, konfor ve sosyal refahını en üst düzeyde karşılama kapasitesine sahip olması beklenir. İnsanın bir diğer bireyle ve mekânla kurduğu ilişkinin mekânsal düzlemi olan tüm tasarımlardan; birey gereksinimlerini karşılamada erişebilir, kullanılabilir ve yaşanabilir olmasının yanı sıra bireyin arzu ettiği etkinlikleri/gereksinimleri de kolaylıkla tecrübe etmeye imkân verme kapasitesinde olması beklenmektedir. Bu beklentilerin evrensel normlarla standartlaştırıldığı 'erişebilirlik' kavramının epistemolojik ve ontolojik değeri, dünya kentlerindeki engelli ve yaşlıları da içeren tüm nüfusu kucaklama ve içerebilme kapasitesinde gizlidir.

Konunun ve kavramın önemi, dünyada demografik yapı içinde artan yaşlı/engelli nüfusu da dâhil olmak üzere, tüm kent kullanıcılarını kuşatan ve her bireye uygun tasarımın planlanmasının, hayata geçirilmesinin ihtiyacından temellenmektedir. Kentlerin önemli bir bölümünü kucaklayan geleneksel yerleşim alanındaki yapıların korunması ve sürdürülebilirliğinin gerçekleștirilmesine yönelik çalışmaların yanı sıra sosyal yaşamın daha güvenli olması ve yaşam akışını kolaylaştırılması bağlamında erişebilirlik standartlarının da arttırılması gerekmektedir. Kentin her noktasında sunulması beklenen erişilebilirlik hizmetlerinin geleneksel yerleșim alanlarında da tasarlanmıs olması, varsa iyileștirilmesi; yoksa planlanması günümüz gereksinimlerinden biri olarak karşımıza çıkmaktadır. Bu gereksinimin karşılanması sırasında bireyin ait olduğu yerleşim alanları ve yaşam biçiminden kopmadan, mevcut ilişkilerini ve sosyal sermayesini koruyarak yaşamını idame ettirmesi için kentin geleneksel yerleşim alanlarında da erişilebilirlik düzenlemelerine ihtiyaç duyulmaktadır. Geleneksel yerleșim alanlarında hayatı kolaylaștırması beklenen düzenlemeler, evrensel tasarım ve erișebilirlik gibi kullanımı kolay ve amaca uygun tasarımlar olarak hayata geçirilirse, tüm kullanıcıların yaşamını kolaylaştıran imkânlar sağlayarak sürdürülebilir geleneksel yerleşim alanlarındaki yapıları mekânsal bağlamda ve sosyal konfor açısından daha tercih edilir kılacaktır.

\footnotetext{
${ }^{1}$ Dr. Öğr. Üyesi, Firat Üniversitesi, Mimarlık Fakültesi, Mimarlık Bölümü, E-Posta: nihalardaa@hotmail. com ORCID: 0000-0003-1948-188X

2 Araş. Gör., Fırat Üniversitesi, Mimarlık Fakültesi, Mimarlık Bölümü, E-Posta: tubanurbaz@gmail.com ORCID: 0000-0001-5654-0020

AKYILDIZ, N., OLĞUN, T. (2020). Geleneksel Yapılarda Yaşlı Ve Engelli Erişilebilirliğinin İrdelenmesi: Malatya-Balaban Geleneksel Evleri Örneği. Sosyal Politika Çalışmaları Dergisi, "Erişilebilirlik" Özel Sayısı Cilt 1, 31-48. DOI: 10.21560/spcd.vi.817603
} 
Çalışma, geçmişte 'mimarsız' olarak hayata geçirilen geleneksel yerleşim alanları ve yapıların; erişilebilirlik konusundaki eksikleri, aile yapısı/komşuluk dayanışması ile nasıl çözdüğünü ve günümüzde bu anlamda yapılan çalışmalarda 'erişilebilirlik' konusuna ilişkin standartların ne kadarını karşıladığını ortaya koymayı hedeflemektedir. Çalışmada toplumsal yaşam içinde erişilebilirlikle ilgili sorunları, geleneksel yapıların kendine özgü tasarım modeliyle kendi içinde çözmeye çalışan bir sistem olduğunu ortaya koymak üzere; Malatyảnın Darende ilçesine bağlı Balaban beldesindeki geleneksel yerleşim alanı incelenmiştir. Bu bağlamda konuyla ilgili literatür araştırmaları ve yerinde yapılan alan incelemeleri, çalışmanın temel yöntemini oluşturmaktadır. Çalışma sonucunda elde edilen verilerin geleneksel yapılar için korumaya yönelik düzenlemelerin yanında erişilebilirlik standartlarının da arttırılması gerekliliğine ve bu yerleşim alanlarının söz konusu bağlamda yaşatılmasının önemine vurgu yapacağı düşünülmektedir.

Anahtar Kelimeler: Geleneksel Yapı, Erişilebilirlik, Malatya, Balaban 


\title{
INVESTIGATION OF ELDERLY AND DISABLED ACCESSIBILITY IN TRADITIONAL BUILDINGS: THE CASE OF MALATYA-BALABAN TRADITIONAL HOUSES
}

\begin{abstract}
In every design made for human; it is expected to have the capacity to meet the quality of life, health, safety, comfort and social welfare of the individual at the highest level. Of all the designs that are the spatial plane of the relationship the human establishes with another individual and space; in addition to being accessible, usable and livable in meeting the individual's needs, it is expected to have the capacity to easily experience the activities / needs of the individual. The epistemological and ontological value of the concept of 'accessibility', in which these expectations are standardized by universal norms, is hidden in its capacity to embrace and include the entire population, including disabled and elderly people, in world cities.

The importance of the subject and the concept is based on the need to plan and implement a design that encompasses all urban users and is suitable for each individual, including the increasing population of elderly / disabled people in the world in terms of demographic structure. In addition to the studies for the conservation and sustainability of the buildings in the traditional settlement area that embraces a significant part of the cities, it is necessary to increase the accessibility standards in the context of making social life safer and facilitating the flow of life. Accessibility services expected to be offered at every point of the city should also be designed in traditional residential areas, and if any, improved; otherwise, planning appears as one of today's needs. While meeting this requirement, accessibility arrangements are also needed in the traditional residential areas of the city in order for the individual to maintain his life by conserving his existing relations and social capital without breaking away from the residential areas and lifestyle. If the arrangements expected to facilitate life in traditional residential areas are implemented as easy-to-use and purposeful designs such as universal design and accessibility, they will make the buildings in sustainable traditional residential areas more preferable in terms of spatial and social comfort by providing opportunities that facilitate the lives of all users.

The work is based on traditional residential areas and buildings that were implemented as 'without architects' in the past; it aims to reveal how it solves the deficiencies in accessibility with family structure/neighborhood solidarity and to what extent it meets the standards on 'accessibility' in studies conducted in this sense today. In the study, in order to reveal that traditional buildings are a system that tries to solve the problems of accessibility in social life with its own design model; the traditional settlement area in Balaban town of Malatya's Darende district was studied. In this context, literature research and on-site field studies are the main methods of the study. It is thought that the data obtained as a result of the study will emphasize the necessity of increasing the accessibility standards as well as the conservation regulations for traditional buildings and the importance of keeping these residential areas alive in this context.
\end{abstract}

Keywords: Traditional Structure, Accessibility, Malatya, Balaban 


\section{GİRIŞ}

Tüm dünyada olduğu gibi Türkiye'de de yaşanan demografik dönüşüm süreci, nüfus kadar toplumsal yapıyı da gelenekselden moderne doğru dönüştürmüş; bu sırada aile yapısı ve aile içindeki bireylerle bir arada yaşama geleneği ve mekânsal tercihler de evrilmiştir. Değişen sosyal hayat revizyonu, kent yapılarını, geleneksel yerleşim bölgelerindeki mekânsal ve sosyal yapıyı, toplumun mekân kullanma alışkanlıklarını değiştirdiği gibi; aile yapısı ve komşulukla birlikte dayanışma ve kaynaşma duygu/ruhunu da dönüştürmüştür (Akyıldız, 2018, s.118). Kentlerin geleneksel yerleşim alanlarında bireylerin yaşam rutinleri köklü alışkanlıklarla süregelirken; zaman içinde değişen tüketim alışkanlıkları, boş vakitleri geçirme araçları, geleneksel toplum yapısı çağın getirdiği yeniliklerle birlikte, toplum yapısı kadar geleneksel yerleşim alanlarını da dönüştürmüştür.

Değişen ekonomik sistemlerle birlikte yaşanan toplumsal süreçler, mekân üretim ve temsillerini değiştirerek; yeni mekân anlayışıyla mekân üretim biçimini ‘diyalektik bir yaklaşımla’ inşa etmiştir. Mekânsal pratikler ve yeniden mekân üretim süreci, toplumsal ilişkilerle sürekli olarak etkileşim halinde olmuştur. Bu nedenle Lefebvre, mekân üretim sürecinde şehircilik/şehir planlanma disiplinlerini, yeni mekân üretim sistemlerini makul kılmak üzere dizayn edilmiş stratejik araçlar olarak kabul etmektedir (Lefebvre, 2014, s.68). $\mathrm{Bu}$ nedenledir ki geçmişin geleneksel yerleşim bölgelerinin aksine, bugünün modern kentlerinde iktidar, bürokrasi, teknik gelişmeler gibi pek çok etkenle birlikte zamanı harcama ve mekânı kullanma alışkanlıklarında da büyük değişim ve dönüşümler yaşanmaktadır (Çelik, 2010, s.29).

Geleneksel yapılar, usta-çırak ilişkisi ile öğrenilen en basit yapım tekniklerinin doğal malzemelerle bütünleştirilmesiyle ve belli bir tasarımcının etkisi olmadan, ihtiyaçlara göre inşa edilen; doğal çevreye, yaşam alışkanlıklarına ve en önemlisi de insana saygı önceliğiyle geliştirilmiş ve hayat bulmuş birimlerdir. Bu nedenle geleneksel yerleşim alanlarını oluşturan geleneksel yapılar, koruma ve sürdürülebilirlik alanlarındaki çalışmaların olduğu kadar; sosyal ve kültürel çalışmaların da önemli bir alanı olmuştur. Bu anlamda son yıllarda sıkça tartışılan sürdürülebilirlik kavramı uygulamalarda ekonomik, kültürel, sosyal ve mekânsal bileşenlerle yerleşim 
alanlarının değerini arttırma kapasitesinde olmuştur. Koruma çalışmalarının ise geleneksel yerleşim alanlarında restorasyon ve restitüsyon çalışmaları ile gerçekleştirildiği ve yerleşim alanlarını daha cazip kıldığı muhakkaktır. Tüm bu çalışmalar içinde ihmal edilen erişilebilirlik düzenlemeleri, en az sürdürülebilirlik ve koruma stratejileri kadar kıymetli olmasına rağmen henüz istenen seviyelerde değildir. Kente dair tüm mekânsal planlamalarda, erişilebilirliğin titizlikle uygulaması, yaygınlaştırılması ve geliştirilmesinin; toplumsal yaşam kadar ekonomik, mekânsal, sosyal ve kültürel yaşama da olumlu katkılar sağlayacağı düşünülmektedir (Elmac1, 2019, s.56).

Yaş, yetenek ve kapasiteleri ne olursa olsun tüm bireyler; kentlerde, hareket ve iletişim değerine sahip mekânsal/işlevsel kullanım olanakları sağlayan yerleşim alanlarına ve mekânlara ihtiyaç duymuşlardır (Özdemir, 2017). Her yaş ve kapasitedeki kullanıcının, sosyal ve kültürel yaşamdan soyutlanmadan bir arada olmalarını sağlayacak planlama, tasarım ve uygulama çalışmaları; sosyal, fiziksel ve ruhsal sağlığı güçlü toplumları yaratırken aynı zamanda yaşam kalitesi yüksek kentleri de oluşturmaya destek sağlamaktadırlar (Aygün vd, 2018, s.31). Bu nedenle erişilebilirliği geleneksel mimaride değerlendirerek, engelli, geçici engelli, yaşlı vb. bireylerin erişilebilirliğini engelleyen kısıtlayıcıların belirlenmesi, belirlenen bu kısıtlayıcılar doğrultusunda çalışmalar yapılması büyük önem taşımaktadır. Yapılı çevrede erişilebilirliği sağlamanın zor olduğu kabul edilerek, yapıların özgünlügünü bozmayacak şekilde çözümler üretilmesi önemli bir olgudur. Bu çalışma, geleneksel yapıların sürdürülebilirliği ve korunmasının yanı sıra erişilebilirliğinin destekleneceği yaklaşımları vurgulamayı ve bireylerin herhangi birinin desteğini almadan sosyalleşebileceği yapı kriterlerini göz önünde bulundurmayı hedeflemektedir.

\section{YAŞLI VE ENGELLI BİREYLERİN TOPLUMSAL HAYATA KATILIM HAKKI}

Tüm dünyada önemli bir nüfus diliminin kısıtlı hareket gücünü simgeleyen 'engellilik' kavramı $\mathrm{AB}$ ile uyum sürecinde kendine farklı bir boyut kazandırmıştır. Avrupa Birliği son yıllarda engelliliği yeni bir yaklaşımla tanımlayarak engellileri yardıma muhtaç olan insanlar olarak görmeyi bir kenara bırakmış; onları diğer bireylerle eşit haklara sahip ve toplumla bütünleşme gayretinde olan bir topluluk olarak görmeyi tercih etmiştir. 
Konuyla ilgili olarak, Birleşmiş Milletler Genel Kurulu İnsan Hakları Evrensel Beyannamesi'nde engelli bireylerin diğer insanlarla eşit hak ve sorumluluklara sahip olduğu düşüncesi vurgulanmıştır.

Avrupa Birliği (AB) Temel Haklar Bildirgesi’nin 26. maddesinde, engelli kişilerin toplumla bütünleştirilmesi için; onların bağımsızlıkları, sosyal ve mesleki yaşamla bütünleştirilmeleri ve toplumsal yaşama katılım haklarına yönelik iyileştirmelerinin sağlanması; bununla birlikte tüm imkânlardan yararlanma hakkının tanınması konuları vurgulanmıștır. Ayrıca bu bireylerin ayırımcılığa maruz bırakılmadan saygı görmelerinin de sağlanmasının önemi belirtilmiştir. (Avrupa Birliği Türkiye Delegasyonu, 2018). Buna ek olarak Dünya Sağlık Örgütü (WHO) "International Classification of Functioning, Disability and Healty ICF 2001" adlı sistemle engellilik kavramını yeni bir tanıma kavuşturmuştur. Daha önce özel bir gruba ait değişmez sınırlılık/ kısıtlılıkları temsil eden engellilik durumu ilk kez 'performans ve yetenek arasındaki ilişki bağlamında’ irdelenmiş ve anlamlandırılmış bu kısıtlılık yelpazesine yaşlılık süreci de dâhil edilmiştir. Herkesin yaşamının bir bölümünde sağlık/yeteneklerindeki oluşabilecek kısıtlama/kayıplarla birlikte yaşamını 'kısmi engelleri tecrübe edebileceği' dinamik bir süreci içine alan koşullara bağlı değişken değerler olarak ele almış (WHO, 2001, s.4,8) ve kısmi engellerin tecrübe edildiği yaşlılı dönemi de bu yelpazeye dâhil edilmiştir. Değişken değerlerle tecrübe edilen yaşlılık kadar engelliliğin de her an yaşanabileceği savından yola çıkarak, 'evrensel tasarım'ın referans kabul edilmesi, engellilik deneyim/tecrübesini en aza indirgeme kapasitesiyle; mekân deneyimleme konusunda uluslararası kriterlerde de kabul görülen ilkelerin hayata geçirilmesi ile ilgili düzenlemelere hız verilmiştir. Konuya ilişkin Türkiye Cumhuriyeti Anayasası'nda da yer alan "sosyal devlet", "sosyal güvenlik hakkı" ve "sosyal güvenlik bakımından özel olarak korunması gerekenler" ile ilgili düzenleme güvencesinin anayasa temelini oluşturduğu görülmektedir. $\mathrm{Bu}$ anlamda ülkemizde konuyu destekler nitelikte hazırlanan 5378 sayılı kanun da, engellilerin bakım, sosyal güvenlik ve mekânsal düzenlemelere ilişkin sorunlarının çözümüne yönelik standartları belirlemek ve geliştirmek üzere öngörülmüş, bu kanun kapsamında engelli ve yaşlı bireylerin sosyal hayata katılımı desteklenmiştir (Akyıldız, 2017, s.7). 
Türkiye açısından bakıldığında -geleneksel yerleşim alanları da dâhil olmak üzere- kentlerin tüm yerleşim alanlarında herkes için tasarım kriterlerinin temelini oluşturan erişilebilirlikle ilgili düzenlemelerin henüz tam anlamıyla yeterli düzeyde olmaması (Menda vd., 2013) ve konuyla ilgili olarak toplumsal açıdan da farkındalık ve duyarlılık düzeylerinin yetersizliği, bu konuda pek çok adıma ihtiyaç duyulduğunu göstermektedir (Çağlar, 2012). Oysaki kentsel yerleşim alanları, insanları birbirine yakınlaştıran bir tür "mikrokozmoz" olarak; bütün içinde farklı geometrik formlarla bir arada bulunana bir "karşılaşma yeri” şeklinde kabul görmektedir (Norberg Schulz, 1980). Bu da kentin yerleşim ve yaşam alanlarını, farklı parçalardan oluşan bütünsel yapısıyla; mekânı yakınlık, süreklilik ve kapalılık kavramlarıyla açıklayabilen düzenlemeler (Erdönmez ve Ak1, 2005) olarak erişimin mekâna ulaşımda ve mekân kullanımındaki önemini ortaya koymaktadır. Bu bağlamda yaşlı ve engelli bireyler de dâhil tüm kent kullanıcılarının mekânsal ve sosyal yaşamına destek olma kapasitesiyle erişebilirlik kavramının açıklanması ve değerinin ortaya konması gerekmektedir.

\section{ERIŞİLEBILIIRLIKK KAVRAMI}

Erişilebilirlik, sadece engellilik düzeyini karşılamadaki hassasiyeti ile değil, insana dair problemleri ve insanın kapasitesine/yaşına ve yeteneklerine duyulan saygıyı da içeren; tüm bireyleri -yaşlı, engelli, çocuk da dâhil- topluma entegre etme çabasıyla önemli bir mekânsal ve sosyal içerme konusudur. Konunun temelini oluşturan engelsiz tasarım ve erişebilirlik mevzusu tüm bireylerin ortak gereksinimlerini karşılayabilen standartların uygulanması konularındaki uğraşlar sonucunda ortaya konmaya başlamıştır.

Her bireyin özgürce ve yardımsız yaşama dâhil olmasına odaklanan erişilebilirlik uygulama esasları ve gerekli standartlarının temeli; kent tasarımlarımda herkes için fayda sağlayan ve bütüncül bir anlayışla "bariyersiz-engelsiz tasarım (barrier-free design)" (Universal Design History, 2008) kavramı doğrultusunda ortaya çıkmıştır. Buradan hareketle herkesin kullanımına imkân veren mekânsal alanların yaratılması da kentleri daha cazip hale getirmiştir (Yılmaz ve Diktaş, 2018, s.134). Evrensel tasarım ilkelerinden referans alarak hayat bulan erişebilirlik düzenleme ve standartları; 
engelli bireyler kadar hareket kısıtlılığı/yavaşlığı yaşayan yaşlıları da yakından ilgilendiren planlamalar olmuştur. Zamanla hareket güçlügü çekmenin yoğunlaştığ 1 yaşlılığın da sakin ve huzurlu geçirilmesi gereken bir yaşam süreci olduğu fikri kabul görse de, yaşlıların demografik yapı içindeki nüfus payı artıkça toplumsal yaşamla ilgili pek çok konuda hâlâ bir takım sıkıntılar yaşanmaktadır. Konu bu bağlamda ekonomik, sosyo-kültürel ve toplumsal hayat açılarından da değerlendirilerek bir takım destekleyici tedbir/fikirlere de ihtiyaç duymuştur (Karatağ ve Akyıldız, 2019, s.576). Bu tedbirlerden biri olan erişilebilirlik, özel ihtiyaç/engelleri olan ve kimi zaman da hareket zorluğu çeken yaşlı ve engellilere uygun teknolojilerden yararlanılarak, mekânsal düzlemlere katılımın en yüksek seviyede sağlandığı özgürlüklerin tümüdür. Bu özgürlükleri sağlamak üzere yapılacak tasarımlar; insan hakları ve sosyal adalet için de toplumsal yaşamı destekleyen bir servis sağlayıcısı olarak görevini yürütmektedir. Bu konu ile ilgili destek mekanizmaları hem sosyo-kültürel hem de mekânsal düzenlemelerle birlikte daha sürdürülebilir bir toplum fikrini sağlayan argümanlardır.

Engelli bireylerin yanı sıra yaşlıların, yapı/kent içinde erişilebilirliği, engel seviye/tiplerine göre değişiklik göstermektedir. Engelli bireyler ve yaşıllar kadar, hamileler ve çocuklar için de yapı içinde birtakım önlemler ve özel düzenlemeler tasarlanması gerektiğinden; bu nüfus dilimine uygun planlamalar tüm kentli nüfusunu içerecektir (Türkyılmaz ve İskender, 2018, s.298). Erişebilirliğin sağlanmasında, kentsel yerleşim bölgelerinin fiziksel olarak; genişlik, alan, yükseklik, yüzey, bildirişim (yönlendirme/ uyarı işaretleri) ve donatı olmak üzere altı temel bileşen; ergonomik tasarım girdisi olarak, kentsel mekan çalışmalarının gerçekleştirilmesi açısından büyük önem taşımaktadır (Andaç, 1997; Altay Baykan, 2007; Aygün vd, 2018, s.21). Buradan hareketle erişebilir tasarım; farklı insanlık durumlarına cevap verecek uygun, esnek ve değişebilir optimum çözümler ve düşük maliyetlerle gerçekleştirilecek planlamaların basit tasarım diliyle hayata geçmesini hedeflemektedir (Türkyılmaz ve İskender, 2018, s.299). Erişilebilirlik uygulamaları sadece rampa veya hissedilebilir yüzeyden ibaret olmayı; toplumsal duyarlılık, farkındalık ve yapılan uygulama standartlarının kontrol eksikliği veya denetim mekanizmasındaki yetersizlikler de en az doğru uygulamalar kadar önemlidir (Arkitera, 2014; Elmac1, 2019, s.36). 
Her yerleşim alanı var olduğu toplumda; hem kendine ait bir dünyayı temsil ederek kültürel izlerini taşır, hem de ekonomik, sosyal ve çevresel değerlerini yaşam birimlerine yansitarak mekânsal anlamda da toplumla irtibat kurar. $\mathrm{Bu}$ anlamda temel ihtiyaçlara cevap verme niteliği taşıyan yerleşim alanları insanla irtibat halinde olup, zamanla değişen talepleri nedeniyle aktif olarak zaman ve mekân diyalogu da fiziksel alanlarda yansımalarını gösterir. Lefebvre, zamanın mekân kavramıyla yakın bir ilişki içinde olduğunu ve bu iki kavramın düz ve lineer bir seyirle de varlığını yürütmediğini belirtmektedir (Lefebvre, 2007, s.7). Bu konu kontrolsüz büyüyen kentleşme içinde, en çok da geleneksel yerleşim alanlarındaki etkisini görünür kılmıştır. Bu bölgelerde zamanla değişen toplumsal ve bireysel ihtiyaçlar, sürekli dönüşen yeni formlara ihtiyaç duyduğundan, yerleşim bölgelerindeki mekân anlayışları ve mekân tasarımları bazı ihmallerle birlikte hayata geçmiştir. Oysaki mekânsal tasarım sürecinde herkes için tasarım ilkesinin referanslarından olan erişilebilirlik anlayışının hedefi; planlama/uygulama sürecinde boyut ve standartların herkes için uygun ve sosyal kısıtlamalardan uzak bir şekilde esnek/özgürlükçü çözümlerle; en önemlisi de kültürel yapıya uygun bir anlayışla tasarlanması ve bunun fiziksel tasarımlara yansıtılmasıdır (Enginöz, 2015; Enginöz ve Şavlı, 2016, s.113). Kentsel mekânlarda; kentsel donatı elemanlarının ergonomik ve standartlara uygun olmayışı, standartlara uymayan eğim ve genişlikteki rampaların yanı sıra, dış mekânlardaki yanlış kot farkları, yanlış ulaşım kararları, yaya öncelikli yolların eksikliği ve kullanılan malzemelerin nitelik/tür yönünden yetersizliği gibi nedenler hem engelli bireyler, hem de yaşllların kent içindeki gündelik yaşam beklentilerini/rollerine pasifleştirici etkiler yaratmıştır (Tandoğan, 2017). Halbuki sağlıklı ve güvenli kentler; mekan erişiminin kolay/erişilebilir ve yaya öncelikli olacak düzende; ayrıca ekolojik ve ekonomik açıdan sürdürülebilir olarak planlanmalıdır. Bununla birlikte kent kullanıcısının yaşam kalitesini arttıran güvenli, estetik ve daha yaşanılabilir kentlerin sürdürülebilir ve uygulanabilir çözümlere kavuşturulması gerekmektedir (Korkut vd., 2017).

Tüm dünyada engelli bireyler ve yaşlıların da demografik yapı içindeki büyüklüğü düşünülecek olursa; kentsel yaşam kalitesi açısından bu bireylerin mekânsal taleplerinin doğru analiziyle, kentsel mekân planlama/tasarım/ uygulama süreçlerinde 'herkes için erişilebilir, kullanılabilir, okunabilir 
ve yaşanılabilir' bir yaklaşımla güvenli ve etkin kullanılabilen mekânların düzenlenmesi insan olmanın gereğidir (Aygün vd, 2018, s.21).

\section{MALATYA-BALABAN YERLEŞIMINININ ERISŞILLEBILIIRLİK YÖNÜNDEN İNCELENMESI}

Ülkemizde pek çok örneği bulunan geleneksel yerleşimler, yaşlı ve engelli erişimi açısından barındırdıkları özgün ve ilham verici nitelikleriyle incelemeye değer verileri bünyelerinde barındırmaktadır. Bu anlamda söz konusu verilerin yoğun olarak görüldüğü yerleşimlerden biri de MalatyaBalaban'dır. Konum olarak Malatya-Kayseri karayolu üzerinde, Darende ilçesine yaklaşık 15 km uzaklıkta bulunan Balaban, çeşitli kaynaklara göre 14 . yüzyılda kurulmuş olan ve yöreye özgü kerpiç malzemeli geleneksel yapıların yoğun olarak bulunduğu köklü bir yerleşimdir (Sözen, 2017) (Şekil 1).

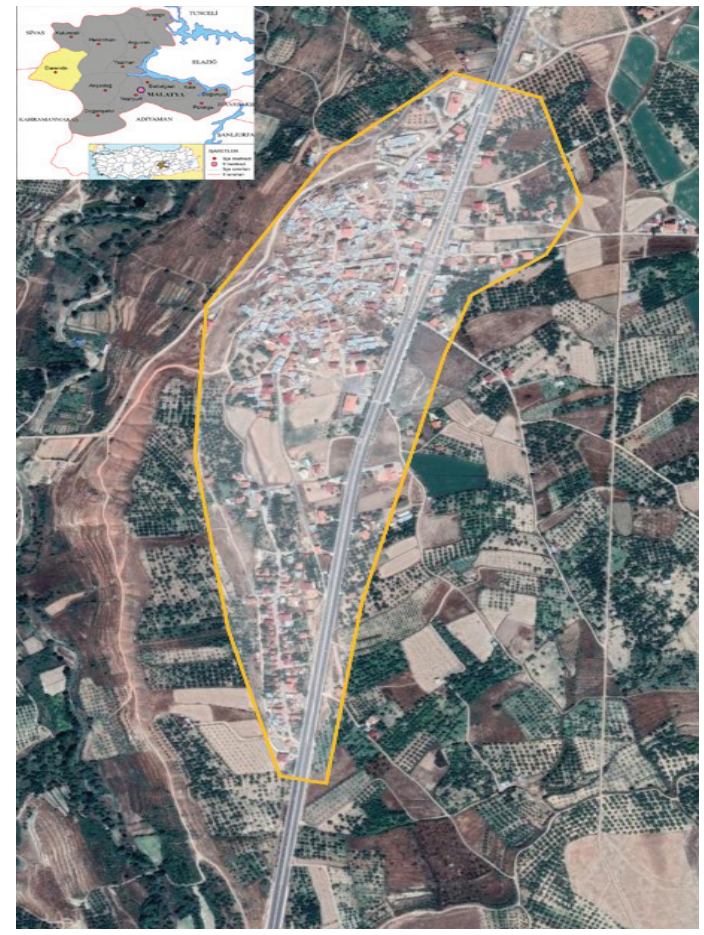

Şekil 1. Balaban yerleşiminin uydu görüntüsü (Google Earth ve URL 1'den yararlanılarak hazırlanmıştır.) 
Kentin her yerleşim bölgesi; sahip olduğu siluetle 'okunaklığı veya görünürlüğüyle’, onu diğer yerleşim bölgelerinden ayıran ve monotonluktan kurtaran 'imgesi ve kimliğine uygun yapılarıyla' varlığını ortaya koymaktadır (Lynch, 2014, s.2,7). Balaban'daki geleneksel yerleşim dokusu da kendine has tarzıyla; genellikle dar sokaklar ve bu sokakların iki yanında sıralanan tek veya iki katlı kerpiç evlerle zengin bir yerleşim alanı olarak özgün kimlik değeri taşıyan yapılarla hayat bulan bir yaşam alanıdır.
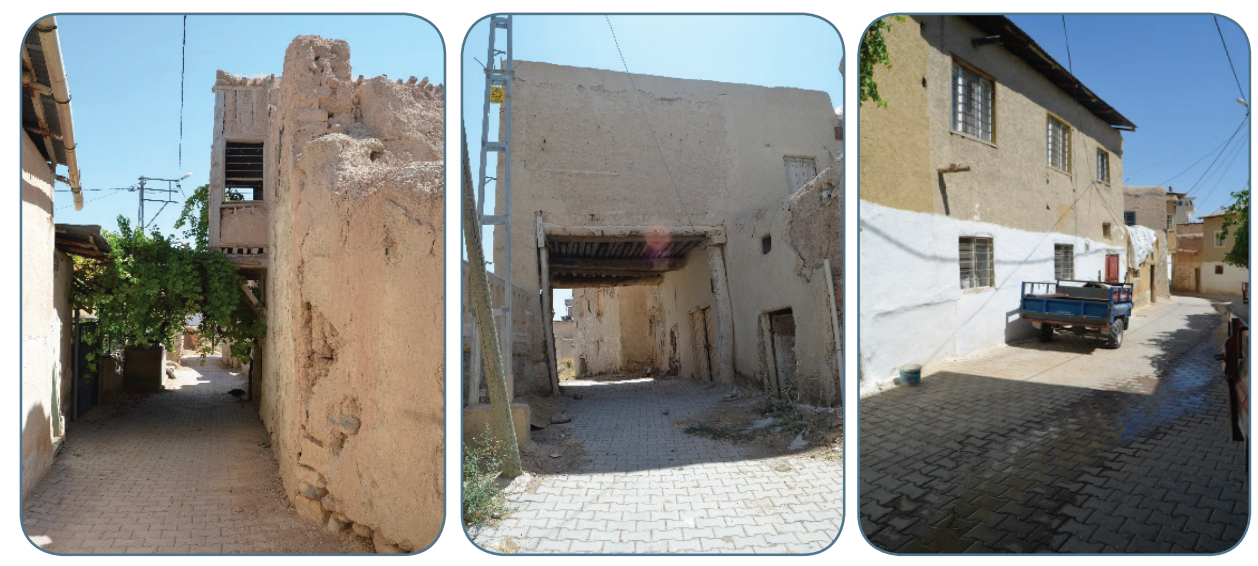

Şekil 2. Balaban geleneksel yerleşim dokusunda bulunan sokak örnekleri

Çoğunlukla evlerin bahçelerinden sokaklara taşan ağaçlar, gölgelik alanları oluşturmaktadır. Ayrıca bazı yapıların yolları aşan ve altından geçit veren, sokakların iki tarafını birbirine bağlayan üst geçit şeklinde bölümleri de bulunmaktadır (Şekil 2). Bu anlamda yerleşim dokusu oldukça özgün niteliklere sahip tarzıyla ilgi çeken bir alandır.

Balaban’n geleneksel dokusunda büyük yeri olan konut yapıları; kerpiç malzemeli, genellikle tek ya da iki katlı, sokağa çıkma yapan, giriş kat cepheleri genellikle sağır ve bu katlarda çoğu zaman depo, mutfak, kiler ve tuvalet gibi mekânların bulunduğu; üst katlarda ise odaların yer aldığı, kendine özgü planlaması olan birimlerdir (Şekil 2 ve 3). 

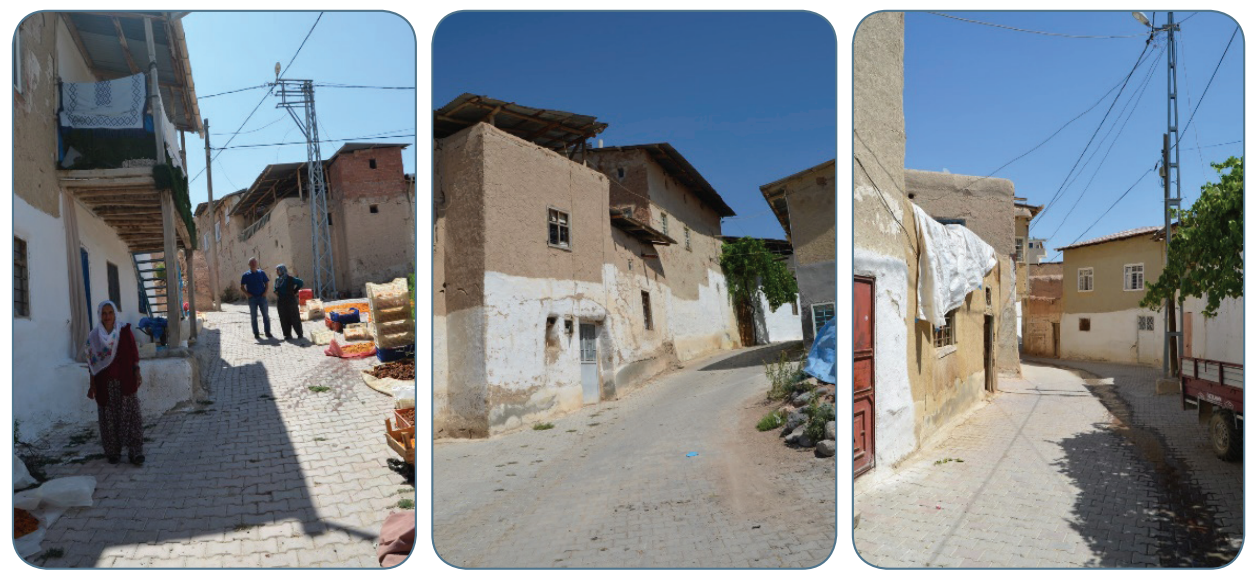

Şekil 3. Balaban geleneksel yerleşim dokusunda bulunan sokak örnekleri

Çoğunlukla avlulu olan bu evlerden bazıları da avlu olmaksızın direk sokaktan giriş almaktadır (Şekil 2 ve 3). Yerleşimin topoğrafyası ile uyumlu bir şekilde konumlanan evlerin girişlerinde ve avlularda neredeyse hiç merdiven ya da basamak bulunmamaktadır. Yalnızca evlerin içinde, üst katlara ulaşmak için merdivenler kullanılmıştır.
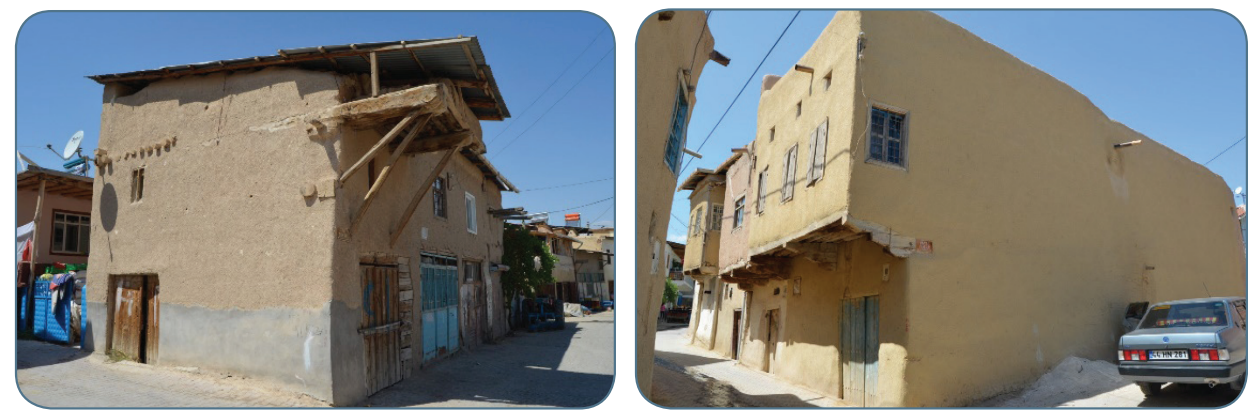

Şekil 4. Balaban geleneksel yerleşim dokusunda bulunan özgün yapılar

Erişilebilirlik, hareket etme ve erişim yeteneğinin bir işareti olarak yaygın biçimde kabul edilmekte olup; sadece engellilerin yaşam kalitesini değil tüm bireylerin de gündelik yaşam düzeylerini destekleyen temel insan hakkı olarak kabul görmektedir (Hall, 2019, s.1). Bu anlamda erişebilirliğin sadece engelli bireyler veya yaşlı bireyler için değil herkes için gerekli olan bir tasarım kararı olduğu, ayrıca sadece yapılarda değil kentsel yerleşim alanlarında da beklenen hassasiyetleri karşılamasının önemi her geçen gün daha da kabul 
gören bir gerçektir (Heitzman, 2005; Tutal, 2018, s.131). Buradan hareketle Balaban'daki yapıların çoğunda merdivensiz bina ve avlu girişlerinin olduğu dikkat çekmekte, bunun da erişebilirlik ile ilgili asgari referansları sorunsuz olarak sağladığı görülmektedir (Şekil 5).

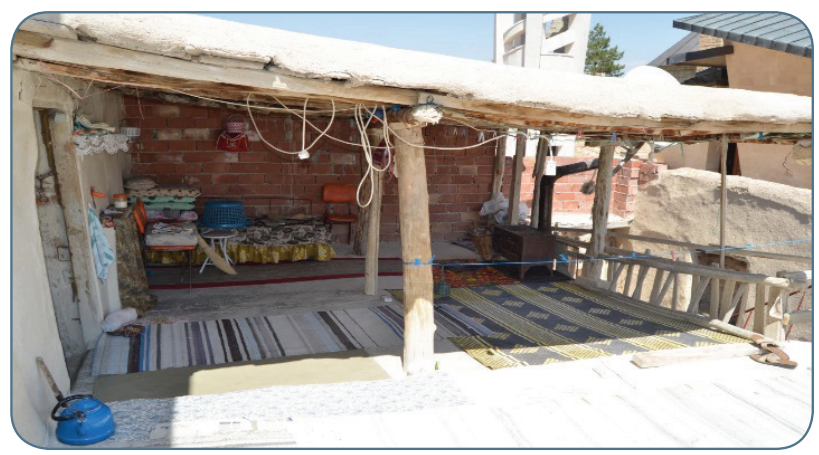

Şekil 5. Balaban geleneksel yerleşim dokusunda bulunan bir yapıda yarı açık oturma birimi

Aile içinde yaşlı ve engelli bireylerin zemin katta yaşamının sürdürülmesine imkân sağlayan küçük boyutlu odaların olduğu bu yerleşim alanında, aynı katta ev halkının da sosyalleşme alanı olarak kullandığı avlu ve hayat bölümünde gündelik yaşamın sağlandığı görülmektedir (Şekil 5). Bu mekânsal düzlem, yaşlı ve engellinin sosyal yaşamını sorunsuz olarak ve yardıma ihtiyaç duyulmadan desteklediği için yerleşimde bulunan bu yapılar, dokuyu özgün kılmaktadır.
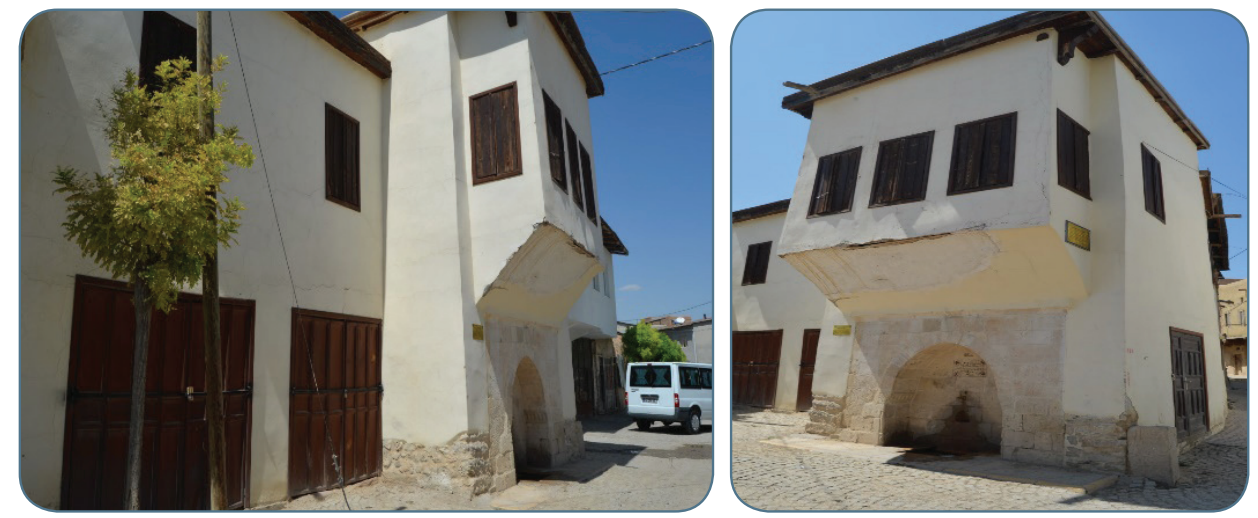

Şekil 6. Balaban geleneksel yerleşim dokusunda yenilenen bir geleneksel yapı 
Yenileme gören yapılarda, yapıların karakteristik özelliklerine dokunmadan onarımların gerçekleştirildiği, sokak yapısını destekleyen çeşme yapısının korunduğu ve yapının ana giriş kararlarına herhangi bir eklemenin de yapılmadığı dikkat çekmektedir (Şekil 6). Pek çok geleneksel yerleşim alanının aksine yapı ve sokak dokularında Balaban'daki mekân çözümlerinin -spontan olarak erişebilirliğe destek sağladığı- yaşlı ve engelli bireylerin sosyal yaşamlarını da pek çok düzlemde desteklediği görülmektedir.

\section{DEĞERLENDİRMELER VE SONUÇ}

Modern mekânlarla birlikte değişen tüketim duygusu, geleneksel kültürel kodlarını, yaşam rutinlerini, günlük alışkanlıkları ve duyguları da dönüştürüp değiştirmiştir. Sosyal yapıdaki bu dönüşüm, mekânsal tercihlerin değişmesini ve geleneksel yerleşim alanlarının terk edilerek kent merkezlerinin tercih edilmesi süreçlerini yaşatmıştır. Geleneksel yerleşim alanları içinde mevcut mekânsal çözümler ve aile-komşuluk ilişki örüntüsünün sağladığ i imkânlarla sosyal hayata aktif olarak katılabilen yaşlılar ve engelli bireyler, modern kent yerleşim alanlarında eski erişim imkânlarına ve sosyal yaşamlarına özlem duymaktadırlar. Kent içinde erişebilirlik çalışmaları -mevzuat gereği- her düzeyde arttırılmaya çalışılsa da eski geleneksel yerleşim alanlarındaki sosyal içerme ve mekânsal erişim düzeylerinin gündelik yaşam seviyelerinde yarattığ 1 sorunsuz sosyal yaşam talep edilir hale gelmiştir.

Geleneksel yerleşim alanlarında mimarsız mimari tasarım kararlarının getirdiği esnek yapı içinde yaşamlarını kolaylıkla ve konforla geçiren yaşlılar ve engelli bireyler; günümüzde bu yerleşim alanlarının, şimdiki kent merkezlerinden olan uzaklığıyla birlikte sosyal hayattan, kültürel etkinliklerden ve gündelik yaşam düzlemlerinden mahrum kalmıştır. Günümüz geleneksel yerleşim alanlarının korunmasında ve yaşatılmasında erişebilirlik konusunun kimiyapılarda dikkatealındığı, kimi yapılarda ise göz ardı edildiğibilinmektedir. Bunun önemli nedenlerinden biri, geleneksel yerleşim alanlarındaki yapıların yapım yıllarının oldukça eski olması ve bu mevzuatla ilgili çalışmaların henüz o yıllarda dikkate alınmaması yatmaktadır. Ancak kimi yerleşim alanlarında aile içinde yaşayan yaşlı ve engellinin de hayatını kolaylaştıracak merdivensiz ev girişleri, avlu/hayat bölümünden yapılara erişim kolaylıkları gibi hassasiyet 
içeren tasarım kararlarının uygulandığı görülmektedir. Bu anlamda geleneksel yerleşim alanlarından biri olan Malatya Balaban yerleşim bölgesindeki sokak dokuları ve yapılar üzerinde yapılan incelemeler doğrultusunda;

- Sokak dokularının eğimsiz, doğal yeşil dokusunun korunarak yaşatıldığı ve düzgün döşenmiş kimi yerde kilit taşı, kimi yerde Arnavut kaldırımı olarak düzenlendiği,

- Sokak bağlantısı ile sağlanan yapı girişlerinin merdivensiz, düzayak olarak tasarlandığ 1

- Kimi evlerde sokak ve yapı arasında bahçe duvarları ile çevrili, yine merdivensiz ve eşiksiz olarak evin hayat bölümüne geçişinin sağlandığı,

- Yapının zemin katında sosyal yaşamın sürdürülmesine imkân sağlayan açık/kapalı mekânların bulunmasının yaşlı veya engelli aile bireyleri için mekânsal düzlemler olduğu,

- Gündelik yaşamın zemin katta sürdürülmesine imkân sağlayan mekânsal düzlemlerin, ev halkı içinde yaşamakta olan engelli ve yaşlının her türlü hal/durum/yetenek kapasitelerini karşılama potansiyelinde olduğu,

- Geleneksel yapılarda herkes için tasarımın mimarsız olarak gerçekleştirilmiş olması ve tüm bireylerin toplumla bütünleşmesine ortam hazırlayabilmesi, toplumda eşitlik, güvenlik ve refah görüşüne de katkılar sunarak daha sürdürülebilir toplumlar yaratmaya zemin sağladığı tespit edilmiştir.

Toplumdan topluma değişen erişebilirlik üzerine düzenleme ve uygulamalarının önemi, mekânsal çözümlerdeki eksiklikleri nedeniyle sadece engelli bireyleri ve yaşlıları değil, tüm toplumun sosyal yaşam akışını etkilemesi nedeniyle daha büyük özen gösterilmesi gereken bir husus olmuştur. $\mathrm{Bu}$ anlamda konu, özelde çalışma alanını ilgilendirse de genel olarak geleneksel yerleşim bölgelerindeki mimari yapı ve sokak dokularında;

- Özgün yapısı, sokaktan düzayak erişimi, avludan eve dağılım veya alt katta yaşlı veya engelli için yaşam imkânı sağlayan mimari yapım sistemlerinin korunma kararlarında dikkate alınarak yaşatılması hususunda farkındalığın ve bilinçlenmenin arttırılması,

- Çalışmaya konu olan yerleşim bölgesindeki yapıların ve sokakların hayat bulmasını sağlayacak restorasyon çalışmalarıyla desteklenmesinin gerektiği, 
- Terk edilen kimi yapıların sahiplenilmesi ve geri dönüş projeleriyle yaşl1sını ve engellisini kucaklayan aile yapısını destekler nitelikte ekonomik ve sosyal imkânların sağlanması hususunda devlet ve yerel yönetim desteğinin gündeme getirilmesinin önemli olduğu,

- Erişebilirlik çalışmaları anlamında sunulan projelere konu edilerek geleneksel yerleşim alanlarının bilinenin aksine yaşlı ve engelli yaşamını destekler nitelikteki tasarım anlayışının çalıştay/sempozyum/bilimsel araştırmalara konu edilmesinin gerektiği,

- Bölge turizmini desteklemek üzere, bu bölgenin mekânsal yapısının desteklenmesi, mevcut erişebilirlik niteliklerinin daha da arttırılarak sadece bölge halkına değil, yerli ve yabancı turizme de kazandırılmasının önemi konularında çalışmaların arttırılması gerekmektedir.

Günümüzde pek çok geleneksel yerleşim alanlarındaki yapılarda; -mimarsız- yerel ustalar aracılığıyla doğal yapıya, topografyaya uyumun yanı sıra bölge halkının hassasiyetleri, aile yapısına uygun tasarım kararlarıyla inşa edildiği ortaya konmuştur. $\mathrm{Bu}$ anlamda sürdürülebilir mekânsal ve sosyal yaşama destek veren yerleşim alanlarının, kentin bu bölgesine özgün bir değer kattığı da tespit edilmiştir. Bu bağlamda geleneksel ve yöresel mimari yöntemlerle hayat bulan söz konusu yerleşim alanı; çevresel verileri dikkate alan planlama kararlarının yanı sıra aile içindeki yaşlı ve engelli bireylerin gündelik yaşam seviyelerini destekler nitelikteki tasarım kararlarıyla da dikkate alınmalıdır. Geleneksel yerleşim alanlarına has özgün sürdürülebilir mekânsal planlama ilkelerinin değeri kabul edilerek, tekrar eski cazip yerleşim alanı olma kapasitesine kavuşturulmalıdır. 


\section{KAYNAKÇA}

Akyıldız, N. A. (2017). Avrupa Birliği ve Türkiye’de Engelli Politikaları. Ankara: Grafiker Yayınları.

Akyıldız, N. A. (2018). Doğu ve Batı Mekânsal Tasarım Sürecinin Aktif Yaşlanma Açısından Ele Alınışı. Ankara: Grafiker Yayınları.

Altay Baykan, D. (2007). Engelli Kentimizde Erişilebilirliği Sağlamaya Yönelik Pilot Proje: 'Bestekâr Sokakta Engel-le-me Projesi'. TMMOB Mimarlar Odası Ankara Şubesi, 4(46), 45-50.

Andaç, G. (1997). Ulaşılabilirlikte Boyutsal Kriterler. Ankara: Yapı Dünyası.

Arkitera (2014). Erişilebilirlik mi Dediniz?, Erişim Tarihi: 23.03.2020, https://www.arkitera. com/haber/ erisilebilirlik-mi-dediniz/.

Avrupa Birliği Türkiye Delegasyonu. (2018). Avrupa Birliği Temel Haklar Bildirgesi, Erişim Tarihi: 25.03.2020, https://www.avrupa.info.tr/tr/avrupa-birligi-temel-haklar-bildirgesi-708.

Aygün, E., Korkut, A. ve Kiper, T. (2018). Engelli Bireyler İçin Kentsel Dış Mekânlara Erişilebilirliğin İncelenmesi: Tekirdağ Örneği. Artium, 6(2), 20-32.

Çağlar, S. (2012). Engellilerin Erişebilirlik Hakkı ve Türkiyede Erişebilirlikleri. Ankara Üniversitesi Hukuk Fakültesi Dergisi, 61(2), 541-598.

Çelik, C. (2010). Şehrin Zamanından Zamanın Şehrine. Muhafazakâr Düşünce DergisiŞehir Hayatı, 23, 29-39.

Elmacı, D. (2019). Avrupa’da Erişilebilirlik Uygulamaları: Borås ve Cardıff Örneklerinin İncelenmesi ve Değerlendirilmesi. Sosyal Politika Çalışmaları Dergisi, 19(43), 33-60.

Enginöz, E. B. (2015). Erişilebilir Mimarlık. Mimarlık Dergisi, Dosya 381.

Enginöz, E. B. ve Şavlı, H. (2016). Metro İstasyonlarında Engelliler İçin Erişebilirliğin İncelenmesi. II. Ulusal Engellileştirilenler Sempozyumu, Konya, 112-121.

Erdönmez, M. E. ve Akı, A. (2005). Açık Kamusal Kent Mekânlarının Toplum İlişkilerindeki Etkileri. Megaron YTÜ Mim. Fak. e-Dergisi, 1(1), 67-87.

Fernandes, J., Emanuel P., Dabaieh, M, Mateus, R. and Bragança, L. (2014). The influence of the Mediterranean Climate on Vernacular Architecture: A Comparative Analysis between The Vernacular Responsive Architecture of Southern Portugal and North of Egypt. World SB 14 Barcelona Conference, 1-7. 
Hall, E. (2019). "Accessibility" In International Encyclopedia of Human Geography (Second Edition). Elsevier. 2(1), 1-8.

Heitzman, F. E. (2005). Universal Access in Historic Buildings. AIA, ASID. Retrieved from http://academics.triton.edu/faculty/fheitzman/ihpabroc hure.html

Google Earth (2020). Malatya-Balaban uydu görüntüleri.

Karatağ, H. ve Akyıldız, N. A. (2019). Avrupảnın Demografik Dönüşümünde Uzun Dönem Yaşlı Bakımının Sürdürülebilirliğinin Değerlendirilmesi. Sosyal Politika Çalışmaları Dergisi, 19(44), 571-596.

Korkut, A., Kiper, T. ve Üstün Topal, T. (2017). Kentsel Peyzaj Tasarımda Ekolojik Yaklaşımlar. Artium, 5(1), 14-26.

Lefebvre, H. (2007). Rhythmanalysis- Space, Time and Everyday Life. Elden, S., Moore G. (Ed.), Londra: Continuum.

Lefebvre, H. (2007). The Production of Space. New York: Blackwell Publishing.

Lefebvre, H. (2014). Mekânın Üretimi. (I. Ergüden, Çev.) İstanbul: Sel Yayınları.

Lynch, K. (2014). Kent İmgesi. (İ. Başaran, Çev.) İstanbul: Türkiye İş Bankası Kültür Yayınları.

Malatya Haritası, (2020). Malatya İlçeler Haritası, Erişim Tarihi: 21.10.2020, https://www. milliyet.com.tr/egitim/malatya-haritasi-malatya-ilceleri-nelerdir-malatya-ilininnufusu-kactir-kac-ilcesi-vardir-6311205.

Menda, E., Balkan, N. ve Berktay, N. (2013). Engelsiz Türkiye İçin: Yolun Neresindeyiz? Mevcut Durum ve Öneriler. İstanbul: Sabancı Üniversitesi Yayınları. 